\title{
The Global Expansion of Constitutional Judicial Review: Some historical and comparative perspectives
}

\begin{abstract}
Albert H.Y. Chen*
Once a written constitution has been enacted as the supreme law of the land, the question arises as regards how to ensure that its promises can be translated into reality. There is a world of difference between a paper constitution that is merely nominal or semantic (Loewenstein 1957: 147-153), and a normative constitution that really achieves its intended objectives of constraining and regulating the exercise of political power and securing the enjoyment of human rights. The challenge is one of institutional design: what kind of political and legal structures should be put in place for the purpose of ensuring that the provisions of the constitution will be actually put into practice, preventing or minimizing breaches of such provisions, and providing effective sanctions for such breaches.
\end{abstract}

From the perspective of legal positivism, one of the defining characteristics of law is the existence of sanctions for violations of legal norms. There is a difference in this regard between the enforcement of ordinary law and the enforcement of the constitution. In the case of ordinary law, litigation followed by a judgment rendered by a court is the main means for its enforcement when disputes arise or crimes are committed. In the course of the development of constitutional law which is intended to bind the political organs of the state, sometimes no clear sanctions are available even if the government acts in breach of a constitutional norm. That is why early legal positivists like John Austin consider constitutional law - as well as public international law - to be rules of political morality rather than law properly so called.

Modern constitutional law has developed various means of 'controls of constitutionality' - means of supervising and guaranteeing the effective implementation of the provisions of the constitution. Cappelletti (1971) draws a distinction between political and judicial controls of constitutionality. Political controls are exercised by political or non-judicial organs of the state. Judicial control of constitutionality, or Verfassungsgerichtsbarkeit in German, is exercised by the judiciary. The principal means of judicial control of constitutionality is

\footnotetext{
* Chan Professor in Constitutional Law, Faculty of Law, University of Hong Kong. It is my honour and privilege to be invited to contribute to this volume in honour of Professor Osanai, for whom I have the greatest respect and admiration as a learned scholar and as a sincere friend. I wish Prof. and Mrs. Osanai the best.
} 
judicial review of the constitutionality of legislation enacted by Parliament, or constitutional judicial review.

In the modern world history of constitutionalism, two well-known models of constitutional judicial review have been developed. They are what is commonly known as the American model of 'decentralised' review by ordinary courts, and the Continental European model of 'centralised' review by a specialized constitutional court. There also exist mixed or hybrid systems which contain features of both the American and European models. Systems of constitutional judicial review also differ in terms of the extent to which the system provides for a stronger or weaker form of judicial review. These different models, structures and forms of constitutional judicial review will be introduced in this chapter with reference to the historical contexts in which they have evolved, their modes of operation and their underlying rationales.

The American model of constitutional judicial review is usually traced back to the legendary decision of the US Supreme Court in Marbury $v$ Madison, ${ }^{1}$ although there is a close relationship between this American system and British colonial constitutional law. In his famous judgment in this case, Chief Justice Marshall pointed out that the power of the legislature is limited by the constitution that has been established by the people; any law made by the legislature that is repugnant to the constitution is void; and it is the power and responsibility of the court to determine what is the applicable legal norm in a particular case where there is a conflict between a statute and the constitution. In the American system of constitutional judicial review that has evolved since Marbury $v$ Madison, every court has the power to review whether a statutory provision is unconstitutional and therefore void. Standing at the apex of the hierarchy of courts, the US Supreme Court is the final court of appeal in deciding whether any statutory provision is inconsistent with the federal constitution of the USA.

Britain does not have a written constitution, and there is therefore no practice of constitutional judicial review. ${ }^{2}$ However, colonies in the British Empire had written constitutions which were enacted by the Crown or Parliament in Britain.

\footnotetext{
1 Cranch 137 (1803).

2 However, under the law of the European Communities (now the European Union), British courts and the European Court of Justice may review and invalidate UK law that is inconsistent with applicable European law. Under the European Convention on Human Rights, the European Court of Human Rights may review the compatibility of UK law with the Convention. After the enactment by the British Parliament of the Human Rights Act 1998, the highest courts in the UK may also review the compatibility of UK law with the Convention (as incorporated into the Act), though they may not invalidate such incompatible law.
} 
Under British colonial law, colonial courts had the power to review whether any provision in an enactment of the colonial legislature was ultra vires the colonial constitution and therefore void. This colonial tradition of constitutional judicial review was inherited by Commonwealth countries such as Canada and Australia. The written constitutions of both Canada and Australia provide for a federal system characterized by a constitutionally entrenched division of power between the federal government and the provincial or state governments. Thus constitutional judicial review in these jurisdictions has been mainly concerned with the enforcement of this federal division of power, until Canada in 1982 enacted, by way of constitutional amendment, the Canadian Charter of Rights and Freedoms, which inaugurated in Canada the era of constitutional judicial review in the domain of human rights protection. Constitutional judicial review by ordinary courts is also practised to varying extents in newly independent countries which were formerly parts of the British Empire, such as India, Pakistan, Bangladesh, Sri Lanka, and some other common law countries in Asia and Africa, such as Malaysia and Kenya.

The European model of constitutional judicial review by a specialized constitutional court can be traced back to the Austrian constitution of 1920, which, under the influence of Hans Kelsen's jurisprudence, established a constitutional court (Cappelletti 46-7, 71-2). According to Kelsen's theory of the hierarchy of legal norms, the constitution stands at the foundational level, and the validity of all legal norms in a state is ultimately derived from the constitution. Kelsen proposed the creation of a constitutional court which (unlike the ordinary courts) has jurisdiction to determine whether any legal norm is consistent with the constitution. In his view, the constitutional court is the complement to the legislature; it performs a political and legislative function - that of negative legislation, or nullification of an unconstitutional norm. In Kelsen's theory, such constitutional judicial review is limited to dealing with logical inconsistencies between, on the one hand, constitutional norms - particularly norms governing the division of power between various state organs - and, on the other hand, other lower-level legal norms; it is not concerned with the protection of individuals' human rights. ${ }^{3}$

In addition to the constitutional court established under the Austrian constitution of 1920, constitutional review was also established in Czechoslovakia in 1920, in

${ }^{3}$ See generally Kelsen 1942; Kelsen 1961. 
Lichtenstein in 1921, and in Spain in $1931 .^{4}$ In Ireland, the 1937 constitution expressly provided for judicial review of legislation. ${ }^{5}$ The Austrian constitutional court (Verfassungsgericht) epitomised the 'archetypal form' (Cappelletti 69) of the kind of constitutional judicial review that is (a) centralized, (b) abstract review (i.e. review of the constitutionality of a law but not in the context of the facts and circumstances of any concrete case that is litigated before an ordinary court (as distinguished from a constitutional court)) rather than concrete review (as in the American system or the systems in former British colonies, under which the court reviews the constitutionality of a law only where the application of that law is relevant to a case litigated before the court), and (c) review 'principaliter' (i.e. review in a legal action where the principal or only issue is the constitutionality of a law) rather than review 'incidenter' (as in the American system or the systems in former British colonies, where the review is only incidental to the making of a judicial decision as to which party wins the litigated case) (Cappelletti 69). In the Austrian system that existed in 1920-1929, the constitutional court only conducted abstract review of the constitutionality of laws in actions initiated by other governmental organs for the purpose of such review. In particular, the federal executive could request review of laws of the Länder (constituent states of the federation); the governments of the Länder could request review of federal legislation (Cappelletti 72). Hence the purpose of the system was to police the constitutional division of power between the federation and its member states. The Austrian system was modified by the constitutional amendment of 1929, under which the supreme court and central administrative court acquired the right to refer the question of the constitutionality of a law to the constitutional court when such a question arose in cases being tried by them (Cappelletti 72-4). Thus an element of concrete review or review incidenter was introduced into the Austrian system of centralized review by a constitutional court.

Before the Second World War, attempts by ordinary courts in Germany and France to practise the American system of constitutional review were made but did not prove to be successful. In France, '[i]n a few cases the Conseil d'Etat or the Cour de Cassation seemed to avoid giving effect to an unconstitutional law by interpreting it so as to bring it within constitutional limits; but there was no case in which either the Conseil d'Etat or the Cour formally declared a law unconstitutional.' (Favoreu 1990: 43) In Germany, the Weimar constitution of

\footnotetext{
4 Comella 2009: 3.

5 Koopmans 2003: 42.
} 
1919 contained a bill of rights, but was silent on whether the courts could exercise the power of constitutional review of laws. 'During the 1920s, several German courts, including the Supreme Court (the Reichsgericht) suggested that they had power to review the constitutionality of laws.' (Jackson and Tushnet 2006: 528) There also existed the Staatsgerichtshof, a constitutional tribunal that resolved inter-governmental disputes between the Länder (states) of Germany and between a state and the central government. This tribunal also had jurisdiction over impeachment of senior officials. (Jackson and Tushnet 527)

The lack of progress of American-style constitutional review in Continental Europe before the Second World War has been attributed to several factors. (Favoreu 44-5) First, the European conception of law had been much influenced by Rousseau's idea of law as the expression of general will; the law enacted by Parliament was therefore supreme. Secondly, European judges were skilled mainly in the technical application of legal rules, and were not prepared to exercise the 'value-oriented, quasi-political functions involved in judicial review.' (Favoreu 45) Thirdly, the organization of the court systems in European countries, particularly the plurality of courts specializing in different subject-matters and the lack of a single supreme court for all matters, was not conducive to the development of American-style judicial review. Finally, the supremacy of the constitution was not completely established in some European countries. For example, in Weimar Germany, a law enacted by the Reichstag by a two-thirds majority would be valid even if it appeared to be inconsistent with the constitutional guarantee of fundamental rights: thus the constitution could effectively be amended without an express constitutional amendment. (Jackson and Tushnet 526; Favoreu 46)

In Latin America, the influence of the American system of constitutional review was considerable. Brewer-Carias (1989: 128) has pointed out that there is no necessary connection between a legal system based on the common law and the American system of decentralized constitutional review; ${ }^{6}$ nor is there a necessary

\footnotetext{
${ }^{6}$ Brewer-Carias (1989: 186-7) has provided the following examples of common law countries which have a centralized form of constitutional review by a single court: Papau New Guinea, Uganda (under its 1966 constitution), and Ghana (under its constitutions of 1960, 1969, and 1979). He draws three conclusions from his comparative study (1989: 188): 'first, the concentrated system of judicial review can only exist when it is established expressis verbis in a Constitution, ... second, the concentrated system of judicial review is compatible with any legal system, whether common law or roman law legal systems; third, the concentrated system of judicial review does not imply the attribution of the functions of constitutional justice to a special Constitutional Court, Tribunal or Council ... It may also exist when constitutional justice functions are attributed to the existing Supreme Court of the country, ...'
} 
connection between a civil law-based legal system and the Austrian model of centralized review by a constitutional court. Thus some civil law countries in Latin America, including Mexico, Argentina and Brazil, have adopted the American system of constitutional review (Brewer-Carias 128). At the same time, a hybrid system of constitutional judicial review, in which 'the ordinary courts may have power to refuse to apply an unconstitutional law, but only a single court has the power to declare a law invalid,' (Jackson and Tushnet 466) evolved in the course of the $19^{\text {th }}$ century in some Latin American countries, including Venezuela and Columbia (Brewer-Carias 128, 130). By the early $21^{\text {st }}$ century, there are 10 Latin American countries in which the Supreme Court has the power to declare a law unconstitutional and to annul it; in 5 of these 10 countries, there exists a special constitutional chamber in the Supreme Court. ${ }^{7}$ In 6 other Latin American countries, the power of constitutional review is exercised by a specialized constitutional court. ${ }^{8}$ For example, since the 1970s, constitutional courts or 'constitutional guarantees tribunals' have been established in Chile, Ecuador and Peru. ${ }^{9}$ In Argentina and Brazil, a lower court's decision may be brought before the Supreme Court for review by an 'extraordinary recourse of unconstitutionality' (Brewer-Carias 129).

After the Second World War, major developments in constitutional judicial review occurred in Europe. These developments may be understood in the context of the post-War international movement to enhance the protection of human rights, including the adoption by the United Nations of the Universal Declaration of Human Rights in 1948, and the signature of the European Convention on Human Rights and Fundamental Freedoms in 1950 by member states of the Council of Europe. Both the Basic Law (1949) of West Germany and the new Constitution (1947) of Italy provide for the establishment of constitutional courts, which started to operate in these countries in 1951 and 1956 respectively. In France, the Constitution (1958) of the Fifth Republic provides for a constitutional council. Constitutional courts were established in Spain and Portugal in 1978 and 1982 respectively after their transition to democracy. Poland also established a constitutional court in 1985. Another wave of founding of constitutional courts followed the collapse of communism in the former Soviet Union and Eastern Europe. Since the early 1990s, constitutional courts have been established in most of the new democracies in Russia, Eastern and Central Europe.

\footnotetext{
7 Jackson and Tushnet 493; Comella 5.

8 They are Peru, Guatemala, Chile, Ecuador, Bolivia and Colombia: see Comella 5; Jackson and Tushnet 493.

9 Brewer-Carias 190; Comella 5.
} 
By the early $21^{\text {st }}$ century, constitutional courts exist in 18 of the 27 member states of the European Union, while American-style constitutional judicial review exists in Denmark, Sweden, Finland and Switzerland. Ireland, Greece, Cyprus and Estonia have hybrid systems of constitutional review (Comella 154). The Netherlands and the United Kingdom are exceptional in the sense that they do not have a formal mechanism of constitutional review. However, under the Human Rights Act 1998, UK courts may declare the incompatibility of statutory provisions with the European Convention on Human Rights, though they have no power to invalidate such provisions. Dutch courts may review whether legislation is inconsistent with the European Convention on Human Rights, and to strike down statutory provisions that are so inconsistent (Koopmans 44).

From its European and American roots, constitutional judicial review has grown and spread to all parts of the world, and is now clearly a global phenomenon. The institution of constitutional review by ordinary courts is widespread among common law jurisdictions, including former constituents of the British Empire and the Philippines, and has also been introduced in post-War Japan. At the same time, constitutional courts have been established all over the world: the founding of such a court is a particularly clear demonstration that the country concerned has chosen the path of constitutional judicial review. Examples of countries outside the European and American continents which have established constitutional courts include Turkey, Egypt, South Africa, Taiwan (Republic of China), Mongolia, South Korea, Thailand, and Indonesia. It is no coincidence that some of these courts were established in the 1980s (in South Korea), 1990s (in Mongolia, South Africa and Thailand) or the first decade of the $21^{\text {st }}$ century (in Indonesia) at the same time as the transition of their countries from authoritarianism to liberal constitutional democracy, which was also the case in European countries that have undergone such a transition. This shows that in the early $21^{\text {st }}$ century world, a well-developed system of constitutional review is now generally accepted as an essential or desirable feature of a liberal constitutional democracy.

Some explanations have been provided by scholars as regards why many European states and new democracies in other parts of the world chose to establish specialized constitutional courts instead of adopting American-style constitutional review by ordinary courts. In the case of the civil law jurisdictions in Continental Europe, factors which have favoured the option of having a 
constitutional court include the following: ${ }^{10}$ (a) the traditional conception of separation of powers according to which the judiciary (of the ordinary courts) should not engage in the 'political' function of invalidating Acts of Parliament; (b) the absence of a doctrine of stare decisis (binding precedents) in civil law countries, which means that even if one court rules that a statute is unconstitutional, the ruling does not bind other courts; (c) the structure (such as the plurality of courts specializing in different kinds of litigation), procedure, and mentality and training of judges of ordinary courts are such that they may not be effective in performing the task of constitutional review. In the case of countries undergoing a transition from authoritarianism to democracy, existing judges 'would be unlikely to have either the training or the independence from prior regimes to function with legitimacy as constitutional adjudicators'; hence the more viable option is to establish a constitutional court staffed by 'a small number of respected and untainted jurists.' (Jackson and Tushnet 468)

Constitutional courts are often given additional functions other than the review of the constitutionality of laws, such as supervising elections and referenda, determining the legality of political parties, or enforcing the criminal law against senior officials (Comella 6). In the following, the operation of constitutional courts and of decentralized American-style constitutional review will be illustrated with reference to the experience in several countries whose models of constitutional adjudication are widely known and influential. We first consider the Federal Constitutional Court (Bundesverfassungsgericht, or BVerG), originally of West Germany, and subsequently of the united Germany (after 1990). ${ }^{11}$ The court consists of 16 judges divided into two chambers or senates. Half of the judges are elected by the Bundestag (Federal Parliament), and the other half by the Bundesrat (Council of Constituent States). ${ }^{12}$ The types of cases over which the court has jurisdiction include, among others, (a) abstract review (upon the request of certain governmental actors, such as the federal government, a state government, or one-third of the members of the Bundestag); (b) concrete review, which means that other courts may, in the course of hearing cases, refer to the Constitutional Court a question regarding whether a statutory provision is unconstitutional; (c) constitutional complaints (Verfassungsbeschwerde) ${ }^{13}$ by

\footnotetext{
10 Cappelletti 54-66; Jackson and Tushnet 467-468.

11 See generally Kommers 1997.

12 See the Basic Law, art. 94, which also provides that the court 'shall consist of federal judges and other members.' At least 6 of the 16 judges of the court must have served as federal judges. In practice law professors constitute the largest group of appointees to the court, which is also the case in the Italian and Spanish constitutional courts discussed below. See generally Sweet 2000: 48.

13 This can also be translated as 'constitutional recourse' (Cappelletti 22). Generally speaking (but
} 
persons who allege that their basic rights have been violated by governmental actions, including administrative actions and judicial decisions. In practice most of the cases dealt with by the Court arose from constitutional complaints, and most of such complaints were against decisions of other courts. It has been pointed out that the institution of constitutional complaints has contributed to the high standing of the Constitutional Court in the eyes of members of the public, and to the 'rising constitutional consciousness among Germans generally' (Kommers 28). Apart from exercising the power of constitutional review of laws and governmental actions, the Constitutional Court also exercises other powers conferred upon it by the Basic Law and other laws, including the jurisdiction 'to review cases involving the election of members to Parliament; to decide cases brought against the President of the Republic; to adjudicate controversies between constitutional organs, and between the Federal Republic and the Länder, or between two Länder' (Favoreu 52).

The constitutional courts in Italy and Spain share much in common with the German constitutional court. The Italian court consists of 15 judges; Parliament, the President and the judiciary each elects or appoints one-third of them. It has jurisdiction 'over conflicts of jurisdiction between various state authorities and between regions; over allegations against the President of the Republic, the President of the Council of Ministers, and the ministers; the acceptance of abrogative referendums; and constitutional review of laws' (Favoreu 52-3) (including concrete review upon reference by other courts). The Spanish constitutional court, which began to function in 1980, has 12 judges appointed by the king, 4 of whom upon nomination by the Congress, 4 by the Senate, 2 by the government, and 2 by the judiciary. Its jurisdiction includes the resolution of conflicts between state organs, the review of the legality of treaties, the review of the constitutionality of laws (including abstract review upon reference by the President, 50 members of the Congress or of the Senate, etc., and concrete review upon reference by a court in the course of litigation), and dealing with individuals' petitions of amparo against administrative acts and judicial decisions that affect their fundamental rights (Favoreu 54). The writ of amparo was first developed in Latin America, and provides a channel of access to the constitutional court similar to the constitutional complaint in the German system.

subject to exceptions), this remedy can only be pursued when other judicial remedies have been exhausted. The jurisdiction to hear constitutional complaints was not provided in the original Basic Law of 1949 but was first introduced by statute in 1951 and then given constitutional status by the constitutional amendment of 1969. 
It has been pointed out that the operation of European-style constitutional courts is such that there is a trend towards convergence with the American model of constitutional review. ${ }^{14}$ First, the appointment or election of judges of European constitutional courts is a political process, with the political inclinations of nominees being taken into account. In the US, the President's nominees for appointment to the Supreme Court need to be confirmed by Senate, which is also a political process. In practice, more than one-fifth of the nominees have been rejected by Senate. ${ }^{15}$ Secondly, although the US Supreme Court has jurisdiction to hear appeals in all types of cases, in practice constitutional law has become the most important part of its caseload, and thus it performs a function fairly similar to a constitutional court. Thirdly, the US Supreme Court can, by the system of grant or denial of certiorari, select which cases appealed to it from lower courts will be heard by it. Similarly, in the European system, many cases are screened out of the system at a preliminary stage and will not be considered by the constitutional court itself (Dorsen 170). Fourthly, there exist some similarities in terms of the techniques of constitutional interpretation used by, and the remedies granted by, the European constitutional courts and the American courts exercising the power of constitutional review. Finally, the involvement of European constitutional courts in concrete review and individuals' constitutional complaints (which are mainly directed against judicial decisions and administrative actions) means that they are now not primarily concerned with abstract review ${ }^{16}$ - the original function of the Austrian model of constitutional court - but are heavily involved in 'microconstitutional review' (Favoreu 54). In this regard, their function has become more similar to that of the American Supreme Court as the final appellate court for cases decided by lower courts.

Apart from the convergence between the American and European systems of constitutional review, the move towards convergence between the French system and the 'mainstream' European system (as represented by Germany, Italy and Spain) is also noteworthy and demonstrates the increasing appeal of making constitutional justice more widely available to people. Since the French Revolution, the French conception of the nature of legislation (as expressing the 'general will') and the supremacy of Parliament was such that courts did not have any power to review the constitutionality of or to strike down laws enacted by Parliament. The 1958 Constitution of the Fifth Republic established for the first

\footnotetext{
14 See generally Cappelletti (1971) and Favoreu (1990).

15 Jackson and Tushnet 501; Dorsen 2010: 167.

${ }^{16}$ Comella 8. However, abstract review (rather than concrete review) is still dominant in Eastern and Central Europe (ibid.).
} 
time a constitutional council (Conseil Constitutionnel). This constitution departed from the approach of the 1946 constitution and established a strong executive with some law-making powers. The original intent in establishing the constitutional council was to enable it to ensure that Parliament would not encroach upon the powers of the executive. The council consists of 9 members; the President, the chairman of the National Assembly and the chairman of the Senate each appoints one-third of the members. ${ }^{17}$ The council was given the power to review the constitutionality of bills adopted by Parliament before the bills came into effect as laws. This kind of review may be characterized as 'preventive' (preventing an unconstitutional law from coming into force) or 'a priori' review (before the formal promulgation of a law) (Comella 7). Other subject-matters over which the council has jurisdiction include elections, emergency powers, and the constitutionality of treaties. ${ }^{18}$ The role of the constitutional council expanded significantly as a result of and since the council's landmark decision in 1971 in the case of Liberté d'Association, 'which can be called France's Marbury v Madison' (Pech 2004: 91). In this case, which was concerned with the freedom of association, the council asserted and exercised the power to declare a bill to be unconstitutional if it violates the French Declaration of the Rights of Man and the Citizen (of the year 1789), the Preamble to the 1946 Constitution, or 'the fundamental principles recognized by the laws of the Republic.' Since 1971, therefore, the constitutional council could use and has used its power of constitutional review not only to maintain the boundary between the powers of legislative and executive organs, but also to protect human rights. 1974 saw a further expansion of the council's role. Before 1974, the right to request the council to review the constitutionality of bills was restricted to the President, the Prime Minister, and the chairman of each chamber of Parliament. The constitutional reform of 1974 empowered 60 members of either chamber to activate the council's review jurisdiction. ${ }^{19}$ The practice thereby developed that almost every controversial bill would be referred to the council for review (Morton 1988: 90-2). However, the council's power of review was still confined to abstract review, until the constitutional amendment of 2008 which introduced concrete review into the French system for the first time (Comella 8). Under this amendment, courts may, in the course of hearing cases, refer a law that is alleged to violate constitutional rights to the constitutional council, subject to a filtering process involving the two highest courts - the Cour de Cassation (Court of Cassation) and the Conseil d'Etat (Council of State, which is the highest

17 Dorsen 165; Favoreu 53.

18 Bell 1992: 163.

19 There are over 500 Members of Parliament in the National Assembly, and over 300 in the Senate. 
administrative court).

In terms of the structure or organization of constitutional review, the main mode of classification of different systems is that based on the distinction discussed above between American-style decentralized review (which is also prevalent in other former British colonies) and European-style centralized review by a constitutional court. In terms of the form or manner of constitutional review, a possible distinction is that between what can be called a strong form of constitutional judicial review and a weak form. This distinction is based on the relative powers of and relationship between the court (which exercises the power of constitutional review) and the Parliament. Strong constitutional judicial review may be said to exist where the court's determination that a particular law is unconstitutional is final and conclusive, and is binding on all person and organs until and unless the court overrules itself in another case, or a constitutional amendment is enacted which alters the constitutional rule on which the court's original decision was based. Thus strong constitutional judicial review exists in both the USA and Germany, although they practise decentralized and centralized review respectively.

On the other hand, weak constitutional judicial review exists where the court's determination that a particular law is unconstitutional and invalid can be superseded or overridden by a subsequent Act of Parliament (which is not a constitutional amendment) that re-affirms this law by a special majority or even just a simple majority. The most well-known example of this weak form of constitutional judicial review is provided by the case of Canada under its 1982 constitution, which provides for an 'override' mechanism. ${ }^{20}$ Under this mechanism, Parliament may (by a simple majority) validate a statute even if it is inconsistent with certain provisions of the Canadian Charter of Rights and Freedoms as interpreted by the court. Such validation would automatically expire after 5 years unless it is extended. This 'override' mechanism is however not applicable to certain Charter rights that are considered to be essential to the democratic process.

The system introduced in the UK by the Human Rights Act 1998 may be regarded as a form of constitutional judicial review (if we deem the Act to be part of the UK's constitution) that is even weaker than the Canadian review, because the British court may only declare provisions in an Act of Parliament to be

${ }^{20}$ Canada Constitution Act 1982, s. 33. See Dorsen 152. 
inconsistent with the Act (and the European Convention on Human Rights) but has no power to invalidate the provisions. It will then be up to Parliament to decide whether, and if so how, the former Act is to be amended. The 'preventive' or 'a priori' review by the French constitutional council (which is applicable before a law is promulgated and does not therefore involve the invalidation of any law that has come into force), and the 'consultative' review (Cappelletti 2) or advisory or reference jurisdiction (in the form of the Supreme Court - upon request by the government -- delivering an advisory opinion (which is not binding) on a constitutional question) that exists in Canada and India, may also be regarded as weak forms of constitutional judicial review.

The strongest form of constitutional judicial review may be said to exist where the court has - or has successfully claimed -- the power to determine, in the final analysis, whether a constitutional amendment itself is constitutional and valid. For example, in the German Basic Law, the 'eternity clause' (article 79(3)) prohibits constitutional amendments 'affecting the division of the Federation into Länder, the participation on principle of the Länder in legislation, or the basic principles laid down in articles 1 and 20' of the Basic Law. The constitutional court is the ultimate authority for determining, in accordance with the provisions of the constitution including the 'eternity clause,' whether a constitutional amendment isvalid. In India, the Supreme Court has, in the famous Kesavananda Bharati case (in 1973) and subsequent cases, enunciated a doctrine that the 'basic structure' or the basic features of the constitution may not be validly amended, and has successfully asserted the power to determine, in accordance with this 'basic structure' doctrine, whether particular constitutional amendments are valid (Krishnaswamy 2009; Ramachandran 2000). The constitutional court in Taiwan has asserted and exercised a similar power in $2000 .^{21}$ The judicial review of the constitutionality of a constitutional amendment thus exemplifies constitutional judicial review in its strongest form.

Constitutional judicial review, in most of the forms in which it has existed in history and in the contemporary world, involves the invalidation of provisions in Acts of Parliament by a court (such as the supreme court in a decentralized system of constitutional review or the constitutional court) on the ground that the provisions are unconstitutional. Insofar as the court consists of unelected and elitist judges whereas Parliament consists of the elected representatives of the

\footnotetext{
${ }^{21}$ The Council of Grand Justices' Interpretation No. 499 (March 2000): see www.judicial.gov.tw/constitutional court. See also Yeh 2002: 59.
} 
people, the institution of constitutional judicial review is apparently undemocratic or counter-majoritarian, and its legitimacy has thus been questioned from time to time (Bickel 1986). Some jurists defend it by explaining that it enables the values in natural law (as a higher law than positive law) to be realized in a legal system that is largely positivist (Cappelletti 1971); thus constitutional justice through constitutional judicial review contributes to the realization of justice, human dignity and human rights. Others point out that constitutional judicial review is necessary for the maintenance of the basic institutions, processes and conditions of a democratic polity; ${ }^{22}$ democracy or majoritarian rule itself cannot guarantee such maintenance. Furthermore, the rights of minorities need to be safeguarded by constitutional justice, as majoritarian rule may result in such rights being threatened. ${ }^{23}$ Some political scientists point out that in designing a constitutional system, it is rational for actors to choose to establish a system of constitutional justice, so that they themselves may avail of it should they lose in the election and become a minority in, or even absent from, the executive and legislative institutions (Ginsburg 2003). '[I]ndependent judicial review serves a valuable insurance function for competitors in a stable democracy.' (Stephenson 2003: 85) Actually, in many countries in the contemporary world, the traditional conception of separation of three powers for the purpose of check and balance has lost much of its efficacy, because both the executive and legislature may, as a result of elections, fall under the control of the same political party or political force. In this scenario, the availability of the channel of constitutional judicial review - and the existence of an independent judiciary that administers constitutional justice -as a check on the ruling power that dominates both the executive and legislature becomes all the more important and valuable (Koopmans 247-51, Favoreu 56).

\section{REFERENCES}

Bell, John (1992) French Constitutional Law. Oxford: Clarendon Press.

Bickel, Alexander M. (1986) The Least Dangerous Branch, $2^{\text {nd }}$ ed. New Haven: Yale University Press.

Cappelletti, Maruo (1971) Judicial Review in the Contemporary World. Indianapolis: Bobbs-Merrill.

\footnotetext{
22 See, e.g., Ely (1980).

${ }^{23}$ See, e.g., the famous footnote 4 of Justice Stone's opinion in United States v Carolene Products Co (1938) 304 US 144.
} 
Comella, Víctor Ferres (2009) Constitutional Courts and Democratic Values: A European Perspective. New Haven: Yale University Press.

Dorsen, Norman, et al. (2010) Comparative Constitutionalism: Cases and Materials, $2^{\text {nd }}$ ed. St Paul, MN: West.

Ely, John Hart (1980) Democracy and Distrust. Cambridge, Mass.: Harvard University Press.

Favoreu, Louis (1990) 'Constitutional Review in Europe', in Louis Henkin and Albert J. Rosenthal eds., Constitutionalism and Rights: The Influence of the United States Constitution Abroad, pp. 38-62. New York: Columbia University Press.

Ginsburg, Tom (2003) Judicial Review in New Democracies: Constitutional Cases in Asian Courts. Cambridge: Cambridge University Press

Jackson, Vicki C. and Tushnet, Mark (2006) Comparative Constitutional Law, $2^{\text {nd }}$ ed. New York: Foundation Press.

Kelsen, Hans (1942) 'Judicial Review of Legislation: A Comparative Study of the Austrian and the American Constitution', 4 J. Pol. 183.

Kelsen, Hans (1961) General Theory of Law and State, Anders Wedberg trans. New York: Russell.

Kommers, Donald P. (1997) The Constitutional Jurisprudence of the Federal Republic of Germany. Durham: Duke University Press, $2^{\text {nd }}$ ed.

Koopmans, Tim (2003) Courts and Political Institutions: A Comparative View. Cambridge: Cambridge University Press.

Krishnaswamy, Sudhir (2009) Democracy and Constitutionalism in India: A Study of the Basic Structure Doctrine. New Delhi: Oxford University Press.

Loewenstein, Karl (1957) Political Power and the Government Process. Chicago: University of Chicago Press. 
Morton, F.L. (1988) 'Judicial Review in France: A Comparative Analysis', 36 Am. J. Comp. L. 89

Pech, Laurent (2004) 'Rule of Law in France', in Randall Peerenboom ed., Asian Discourses of Rule of Law, pp. 79-112. London: Routledge.

Ramachandran, Raju (2000) 'The Supreme Court and the Basic Structure Doctrine', in B.N. Kirpal et al. eds., Supreme But Not Infallible: Essays in Honour of the Supreme Court of India, pp. 107-133. New Delhi: Oxford University Press.

Stephenson, Matthew C. (2003) 'When the Devil Turns ...': The Political Foundations of Independent Judicial Review', 32 Journal of Legal Studies 59

Sweet, Alec Stone (2000) Governing with Judges: Constitutional Politics in Europe. Oxford: Oxford University Press.

Yeh, Jiunn-Rong (2002) 'Constitutional Reform and Democratization in Taiwan, 1945-2000', in Peter C.Y. Chow ed., Taiwan's Modernization in Global Perspective, pp. 47-77. Westport, Conn.: Praeger. 